\title{
Blockade of 5-HT2a Receptors Reduces Haloperidol-Induced Attenuation of Reward
}

\author{
Faïza Benaliouad ${ }^{1,2}$, Shitij Kapur ${ }^{3}$ and Pierre-Paul Rompré*,1,2 \\ 'Centre de recherche Fernand-Seguin, Hôpital Louis-H Lafontaine, Montréal, QC, Canada; ²Département de psychiatrie, Université de Montréal, \\ Montréal, QC, Canada; ${ }^{3}$ Center for Addiction and Mental Health, University of Toronto, Toronto, ON, Canada
}

\begin{abstract}
Previous studies have shown that effective antipsychotic medications attenuate reward, an effect that is generally attributed to their effectiveness at blocking the dopamine D2-like receptors. As blockade of the serotonin type 2a (5-HT2a) receptors is a common property of the newer antipsychotics, the present study compared the effect of haloperidol, clozapine, and MI 00907 (a selective 5-HT2a antagonist) and the combined effect of haloperidol and MI00907 treatment on brain stimulation reward (BSR). Experiments were performed on male Sprague-Dawley rats trained to produce an operant response to obtain electrical stimulation in the lateral hypothalamus. Measures of reward threshold were determined in different groups of rats using the curve-shift method using fixed current intensity and variable frequency before and at different times after injection of haloperidol $(0.01,0.05,0.1$, and $0.25 \mathrm{mg} / \mathrm{kg})$, clozapine $(\mathrm{I}, 7.5, \mathrm{I}$, and $30 \mathrm{mg} / \mathrm{kg}), \mathrm{MI} 00907(0.033,0.1$, and $0.3 \mathrm{mg} / \mathrm{kg})$, or their vehicle. The effect of MI $00907(0.3 \mathrm{mg} / \mathrm{kg})$ on the attenuation of BSR by a sub- and suprathreshold dose of haloperidol was studied in another group of rats. Clozapine produced a dose-orderly increase in reward threshold with a mean maximal increase of 50\%; at high doses, clozapine induced cessation of responding in several animals at different time periods. Haloperidol induced a dose-dependent increase in reward threshold, with the mean maximal increase (75\%) being observed at the highest dose; it also produced a dose-dependent reduction of maximum rates of responding. MI 00907 failed to alter reward at any of the doses tested and had no effect on the subthreshold dose $(0.01 \mathrm{mg} / \mathrm{kg})$ of haloperidol. But when combined with a suprathreshold dose of haloperidol, MI00907 reduced the reward-attenuating effect of haloperidol. These results show that 5-HT2a receptors are unlikely to constitute a component of the reward-relevant pathway activated by lateral hypothalamic stimulation. However, blockade of 5-HT2a receptors may account for the relatively lower level of reward attenuation produced by clozapine, and predict that antipsychotic medications that have a high affinity for the 5-HT2a receptor may be less likely to induce dysphoria.

Neuropsychopharmacology (2007) 32, 55 I-56I. doi: I0.1038/sj.npp. I 30 I I36; published online I4 June 2006
\end{abstract}

Keywords: antipsychotics; dopamine; dysphoria; MI00907; reward; serotonin

\section{INTRODUCTION}

The dopamine (DA) hypothesis is currently the most prevalent theory concerning the pathophysiology underlying psychotic disorders; it suggests that positive symptoms are associated with a sustained increase in central DA neurotransmission (Hietala et al, 1995; Reith et al, 1994; Seeman, 1987). This hypothesis takes its support in studies showing that indirect DA agonists produce or exacerbate positive symptoms (Farrell et al, 2002; Kapur and Mamo, 2003; Krystal et al, 2005; Laruelle, 2000) and precipitate psychosis in people who are vulnerable (Krystal et al, 2005; Laruelle, 2000), and that clinically effective antipsychotic

*Correspondence: Dr P-P Rompré, Centre de recherche FernandSeguin, Hôpital Louis-H Lafontaine, 7331, Hochelaga, Montréal, QC, Canada HIN 3V2, Tel: + | 5 |4 25| 40I5, Fax: + | 5 |4 25 | 26 I7, E-mail: pierre-paul.rompre@umontreal.ca

Received 27 December 2005; revised 5 April 2006; accepted 16 May 2006

Online publication: 23 May 2006 at http://www.acnp.org/citations/ Npp052306050767/default.pdf medications antagonize DA receptors (Kapur and Mamo, 2003). Whereas the first generation of antipsychotics focused on providing increasingly selective blockade of the DA D2 receptor, the newer generation of antipsychotics (with a few exceptions, eg amisulpride) block the serotonin 2 (5-HT2) receptor in addition to D2. The exact role of these 5-HT2 receptors is a matter of debate. Insofar as the atypical antipsychotic effect can be achieved by amisulpride by itself, it shows that actions on the D2/3 receptor remain sufficient to produce an antipsychotic effect (Kapur and Mamo, 2003). Further, as no clinically antipsychotic drug is devoid of a relevant action on D2 receptors, it is the case that D2 blockade is also necessary for antipsychotic effect (Kapur and Mamo, 2003). However, the newer antipsychotics differ from the typical antipsychotics (especially high doses of these typical agents) in providing lesser extrapyramidal side effects, more improvement in secondary negative symptoms, and better longer term tolerability and outcomes (Kane et al, 1988; Leucht et al, 1999, 2003).

It has been proposed that the 5-HT2 blockade of the atypical antipsychotics is responsible for their superior 
outcomes (Meltzer, 1999). This assertion is supported by the fact that there is a strong functional interaction between 5-HT2a and D2 receptors in limbic brain regions. Electrophysiological studies, for instance, have shown that M100907, a selective 5-HT2a antagonist, attenuates amphetamine and quinpirole-induced inhibition of ventral midbrain DA cell firing. It also produces a strong potentiation of the reversal effect of the selective D2 antagonist, sulpiride, on quinpirole-induced inhibition (Olijslagers et al, 2004, 2005). Activation of 5-HT2a receptors potentiates amphetamine-induced ventral striatal and medial prefrontal cortex (PFC) DA release, an effect prevented by M100907 (Kuroki et al, 2003). On the other hand, M100907 potentiates haloperidol-induced DA release in the medial PFC, whereas it attenuates the stimulant effect of haloperidol on DA in the ventral striatum (Bonaccorso et al, 2002; Liégeois et al, 2002). M100907 also attenuates amphetamine-induced locomotion and disrupts latent inhibition (Sorensen et al, 1993; Moser et al, 1996). Wadenberg et al (1998, 2001) showed that M100907 amplifies the suppression effect of haloperidol and raclopride in a conditioned avoidance response (CAR). In the presence of M100907, for instance, a subthreshold dose of raclopride was found to produce a significant, long-lasting suppression of CAR. Hicks et al (1999) also reported an enhancement of the suppression effect of haloperidol on CAR with injection of M100907 directly into the ventral striatum and into the PFC. Interestingly, when given alone, M100907 has no effect on DA release, spontaneous locomotion, and latent inhibition, and has very weak effect on CAR (see above references). Taken together, these findings suggest that the modulation of DA, and of DAdependent behaviors, by 5-HT2a receptors comes into play only under a state of altered DA neurotransmission.

In this study, we used the brain stimulation reward (BSR) model in an attempt to further investigate the contribution of 5-HT2a blockade to the attenuation of DA-dependent behavior by antipsychotic drugs. We first determined the dose-response effect of clozapine and M100907 on BSR. Then, we studied the effect of 5-HT2a blockade on a suband a suprathreshold dose of haloperidol on this behavior.

\section{MATERIALS AND METHODS}

\section{Animals}

Male Sprague-Dawley rats (Charles River Canada, Montreal, Québec) weighing between 300 and $380 \mathrm{~g}$ at the time of surgery were used. They were housed two per cage before surgery, and individually after the surgery, in a temperature and humidity-controlled room $\left(21 \pm 1^{\circ} \mathrm{C} ; 53 \pm 2 \%\right.$ humidity) with a 12-h light-dark cycle (lights on at 0630 hours). They had free access to food and water and were allowed to habituate for 7 days to the new housing environment. All experimental procedures were performed in accordance with the Guide for the Care and Use of Laboratory Animals, published by the Canadian Council of Animal Care.

\section{Surgery}

Rats were first injected with atropine methylnitrate $(0.4 \mathrm{mg} /$ $\mathrm{kg}$, i.p.) to reduce mucous secretion, anesthetized with sodium pentobarbital ( $65 \mathrm{mg} / \mathrm{kg}$, i.p.), and fixed on a stereotaxic apparatus. Two monopolar electrodes (stainless steel wire of $0.27 \mathrm{~mm}$ diameter) isolated with Epoxy, except for the honed tip, were implanted in the medial forebrain bundle (MFB) at the level of lateral hypothalamus. The stereotaxic coordinates were as follows: $2.8 \mathrm{~mm}$ posterior to bregma, $1.7 \mathrm{~mm}$ lateral to midline, and $8.6 \mathrm{~mm}$ below the skull (Paxinos and Watson, 1986). A bare stainless steel wire was wrapped around four stainless steel screws threaded into the cranium to serve as the indifferent electrode. The whole electrode assembly was fixed to the cranium with dental acrylic. At the end of surgery, procaine penicilline $\mathrm{G} /$ benzathine penicilline $\mathrm{G}$ (15000 u.i.; $0.1 \mathrm{ml}$, i.m.) was injected to prevent infection and $1 \mathrm{ml}$ of physiologic saline was injected to prevent dehydration.

\section{Brain Stimulation Reward}

\section{Apparatus and procedure.}

Training: Behavioral testing was started 1 week following surgery and was carried out in operant chambers $(25 \times 25 \mathrm{~cm})$ made from three opaque polymer walls and one front Plexiglas wall that allowed observation of the animal. Each chamber was equipped with an infrared photocell located inside a hole $(3 \mathrm{~cm}$ diameter, $3 \mathrm{~cm}$ deep) $2 \mathrm{~cm}$ above a wire-mesh floor. To minimize external noise, chambers were encased in ventilated wooden boxes insulated with Styrofoam. Each nose poke response triggered a constant-current pulse generator that delivered a single $500 \mathrm{~ms}$ train of $0.1 \mathrm{~ms}$ cathodal rectangular pulses. The effects of the stimulation at variable intensities (between 200 and $500 \mu \mathrm{A}$ ) was initially tested on each of the electrodes; the site at which the stimulation induced exploratory behavior and forward locomotion with no, or minimal motor effects was chosen. Once operant responding was established (see Rompré, 1995 for details), the animals were trained to respond during discrete 55-s trials, each trial being followed by 30-s interval during which stimulation was not available. The beginning of each trial was signalled by five trains of noncontingent priming stimulation delivered at a rate of $1 \mathrm{~Hz}$. Current intensity was held constant for each animal and the frequency was varied from $98-62$ to $30-10 \mathrm{~Hz}$ in approximately $0.05 \mathrm{log}$ unit steps; the current intensity and the range of frequencies tested were adjusted for each animal to minimize occurrence of behavioral side effects that may interfere with operant responding. Each stimulation train was followed by a 500-ms inter-train interval during which stimulation was not available (see Boye and Rompré, 1996). Data obtained from each discrete trial were used to generate a ratefrequency $(R / F)$ curve from which a measure of the rewarding efficacy of the stimulation (reward threshold) and of performance (maximum rate of nose poke/trial) was derived (see Data analysis; Miliaressis et al, 1986). Reward threshold was defined as the number of pulses/train required to induce a response rate equal to $50 \%$ of the maximal response (M50). Animals were trained in this manner during each daily 70-min test session (four $R / F$ determinations) and drug testing began when the lowest and highest M50 value within a single session ranged by less than $0.1 \log$ unit for 3 consecutive days. 
Drug test: During a single drug test session, three $R / F$ curves were first determined using the procedure described above. Rats were then injected with drug or vehicle and $R / F$ curves were determined again every $30 \mathrm{~min}$ for $4 \mathrm{~h}$. Three groups of rats were tested. The first group $(n=12)$ was tested with four doses $(1,7.5,15$, or $30 \mathrm{mg} / \mathrm{kg})$ of clozapine, the second group $(n=9)$ with four doses $(0.01,0.05,0.1$, or $0.25 \mathrm{mg} / \mathrm{kg}$ ) of haloperidol, and the third group $(n=8)$ with three doses $(0.03,0.1$, or $0.33 \mathrm{mg} / \mathrm{kg}$ ) of M100907. One week separated drug or vehicle tests, and the order of testing was counterbalanced. In a second experiment, we attempted to determine whether blockade of 5-HT2a receptors alters the effect of a subthreshold and a suprathreshold dose of haloperidol with two new groups of rats. A first group was tested on four occasions, once per week, with either vehicle + vehicle, haloperidol $(0.01 \mathrm{mg} / \mathrm{kg})+$ vehicle, vehicle + M100907 (0.3 mg/kg), and haloperidol + M100907. A second group was tested in the same manner with either vehicle + vehicle, haloperidol $(0.05 \mathrm{mg} / \mathrm{kg})+$ vehicle, vehicle + M100907 (0.3 mg/kg), and haloperidol + M100907. Haloperidol was injected 15 min before M100907; the order of drug and vehicle tests was counterbalanced for both groups.

\section{Thermoregulation}

In order to determine the pharmacological activity of M100907 at the dose used in the present study, we tested its effectiveness at attenuating the hyperthermic response to a systemic injection of 1-(2,5-dimethoxy-4-iodophenyl)-2aminopropane (DOI), a 5-HT2a/c agonist. Eight new rats were carried up to a temperature-controlled testing room $\left(21 \pm 1^{\circ} \mathrm{C}\right)$ and allowed to habituate for $1 \mathrm{~h}$. Basal rectal temperature (pre-drug) was first measured by inserting a flexible thermoprobe (Harvard Apparatus, Saint-Laurent, Quebec, model YSI-400) 6-7 cm into the rectum and was kept in place for approximately 30-s while the rat was hand-restrained. Rats were then injected with $0.3 \mathrm{mg} / \mathrm{kg}$ of M100907 or its vehicle, followed $30 \mathrm{~min}$ later by $1 \mathrm{mg} / \mathrm{kg}$ of DOI or its vehicle. Rectal temperature was then measured every $30 \mathrm{~min}$ for $1.5 \mathrm{~h}$.

\section{Histology}

At the end of the experiment, all rats were anesthetized with urethane (1.4 g/kg i.p.) and the stimulation site lesioned by passing through the electrode a direct anodal current (0.1 mA during 15-s). They were then perfused with a $10 \%$ of formalin solution that contained 3\% potassium ferrocyanide, $3 \%$ potassium ferricyanide, and $0.5 \%$ of trichloroacetic acid (Prussian blue technique). Brains were removed and stored in a $30 \%$ sucrose solution until they were soaked. Then they were frozen with 2-methylbutane (99.2\%) and kept at $-80^{\circ} \mathrm{C}$. The brains were later sliced into $35-\mu \mathrm{m}$ sections and were mounted on gelatine-coated glass slides. Slices were stained with thionin (Nissl technique, see Clark, 1981, p 142) and the stimulation site was determined with light microscopic examination.

\section{Drugs}

Clozapine (Sigma-Aldrich, Canada), M100907, or haloperidol (Sigma-Aldrich, Canada) was dissolved in $0.9 \%$ saline solution containing $1 \%$ glacial acetic acid and $0.3 \%$ tartaric acid and injected subcutaneously in a volume of $1 \mathrm{ml} / \mathrm{kg}$. DOI (Sigma-Aldrich, Canada) was dissolved in $0.9 \%$ saline solution and injected intraperitoneally.

\section{Data Analysis}

Reward thresholds obtained under drug and vehicle conditions were expressed as the percentage of pre-injection value (baseline), and group means were calculated. Maximum response rates were also expressed as percent of baseline using the following procedure, and group means calculated. If the maximum response rate on a given $R / F$ curve was obtained at a higher stimulation frequency than that under the baseline condition, response at that frequency was divided by the mean response at the same frequency at baseline and multiplied by 100 . However, if the maximum response rate under drug or vehicle condition was obtained at a lower stimulation frequency than that under the baseline, response obtained under drug or vehicle at the frequency that generated a maximum under baseline was divided by the mean response under baseline and multiplied by 100 . Mean changes of both reward and maximum rate obtained at peak time plasma concentration (near $60 \mathrm{~min}$ after injection for clozapine and M100907, and $90 \mathrm{~min}$ for haloperidol; see Kapur et al, 2003) were analyzed with a one-way ANOVA and comparisons among means made with Duncan's test with the level of significance set at 0.05 (Statistica V6.0, Statsoft). Animals that failed to respond at that time period were excluded from this analysis.

Thermoregulation. Temperature data were analyzed with a two-way ANOVA (treatment and time) for repeated measures on time and comparisons among means made with Duncan's test with the level of significance set at 0.05 (Statistica V6.0, Statsoft).

\section{RESULTS}

\section{Histology}

Of the 50 animals initially prepared for the experiments, 43 were successfully trained and reached the criterion of stability; the others were excluded because the stimulation induced motor movements, the electrode assembly became unstable, or the stimulation site could not be determined owing to technical problems. For the rats that completed the study, histological analysis confirmed that the stimulation sites were located along the MFB between the anterior part of the lateral hypothalamus ( $1.8 \mathrm{~mm}$ posterior to bregma) and the rostral border of posterior hypothalamus $(3.8 \mathrm{~mm}$ posterior to bregma); most of the sites $(>70 \%)$ were located between 2.56 and $3.14 \mathrm{~mm}$ posterior to bregma (see Paxinos and Watson, 1986).

\section{Experiment 1: Effects of Clozapine, Haloperidol, and M100907 on BSR}

Clozapine induced a dose-dependent attenuation of BSR; five out of 12 animals stopped responding at several time periods at 7.5 and $15 \mathrm{mg} / \mathrm{kg}$, whereas eight animals stopped at $30 \mathrm{mg} / \mathrm{kg}$. Figure 1 shows group mean percent changes in 
reward and maximum rate induced by different doses of clozapine for the animals that responded at one or more time periods ( $n$ is different for several time periods owing to cessation of responding). The suppression of reward threshold was dose-dependent and relatively stable across the 4 -h test period (top left panel); the mean maximal suppression reached $50 \%$ and was observed at the highest dose. A one-way ANOVA was performed on data collected at the time of peak time plasma concentration (see Kapur et al, 2003) for those rats that did not stop responding at this time period, revealing a significant effect of treatment $\left(\mathrm{F}_{(4,42)}=7.92, p<0.0001\right)$. Post hoc analysis showed that $7.5 \mathrm{mg} / \mathrm{kg}$ was the lowest effective dose, and that the increase in threshold produced by 15 and $30 \mathrm{mg} / \mathrm{kg}$ was statistically different than that measured at 1.0 but not $7.5 \mathrm{mg} / \mathrm{kg}$ (top right panel). In those animals that did not stop responding, clozapine produced no clear dosedependent effect on maximum rate (Figure 1, bottom panel); it tended to suppress responding at the two lowest doses at $60 \mathrm{~min}$ (bottom right panel), but the oneway ANOVA yielded no significant effect $\left(\mathrm{F}_{(4,42)}=2.04\right.$, $p=0.10$ ).
In order to determine whether repeated treatment with clozapine altered sensitivity of the reward substrate to that drug, we retested the animals with the $7.5 \mathrm{mg}$ dose at the end of the test and compared the results to the first test. Mean percent change in threshold measured at $60 \mathrm{~min}$ postinjection was slightly lower for the second test (first test $=131.3 \pm 10.4$; second test $=122.4 \pm 7.5$ ) but the difference was not statistically significant $(t=1.3, \mathrm{df}=7$, $p=0.23$ ). Likewise, no statistically significant difference between the first and second tests was found for maximum rate (first test $=95.0 \pm 3.7$; second test $=98.4 \pm 6.7 ; t=0.6$, $\mathrm{df}=7, p=0.56)$.

Haloperidol induced a dose-dependent attenuation of BSR; two out of nine animals stopped responding at several time periods at 0.05 and $0.10 \mathrm{mg} / \mathrm{kg}$, whereas three animals stopped at $0.25 \mathrm{mg} / \mathrm{kg}$. Figure 2 shows group mean percent changes in reward and maximum rate induced by different doses of haloperidol for the animals that responded at one or more time period (just like after clozapine, $n$ is different for several time periods owing to cessation of responding). The suppression of reward threshold was dose-dependent and slowly decreased after it reached a peak, near 30-60 $\mathrm{min}$
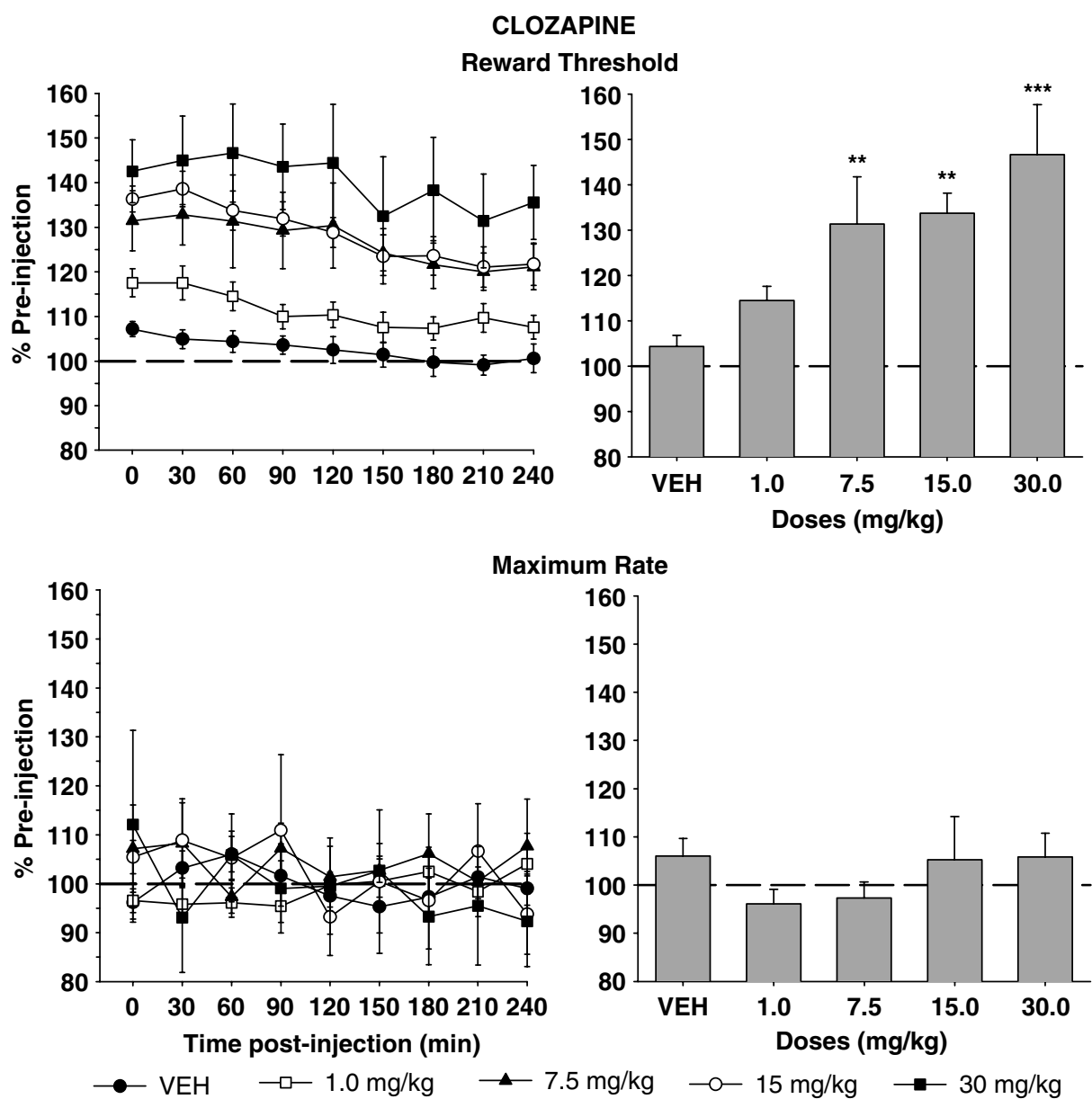

Figure I Group mean $( \pm S E M)$ of reward threshold and maximum rate induced by different doses of clozapine expressed as percent of baseline. The top and bottom left panels show the time course of reward threshold and maximum rate, respectively, for rats that responded during one or more time periods ( $n$ is different for several time periods owing to cessation of responding). The top right panel shows that clozapine induced a dose-dependent increase of reward threshold at $60 \mathrm{~min}$ after clozapine injection (** $<<0.01$ and $* * * p<0.001$ vs vehicle). The bottom right panel shows that clozapine did not induce change in maximum rate. VEH and I mg/kg $(n=12), 7.5 \mathrm{mg} / \mathrm{kg}(n=8), 15 \mathrm{mg} / \mathrm{kg}(n=9)$, and $30 \mathrm{mg} / \mathrm{kg}(n=6)$. 
HALOPERIDOL
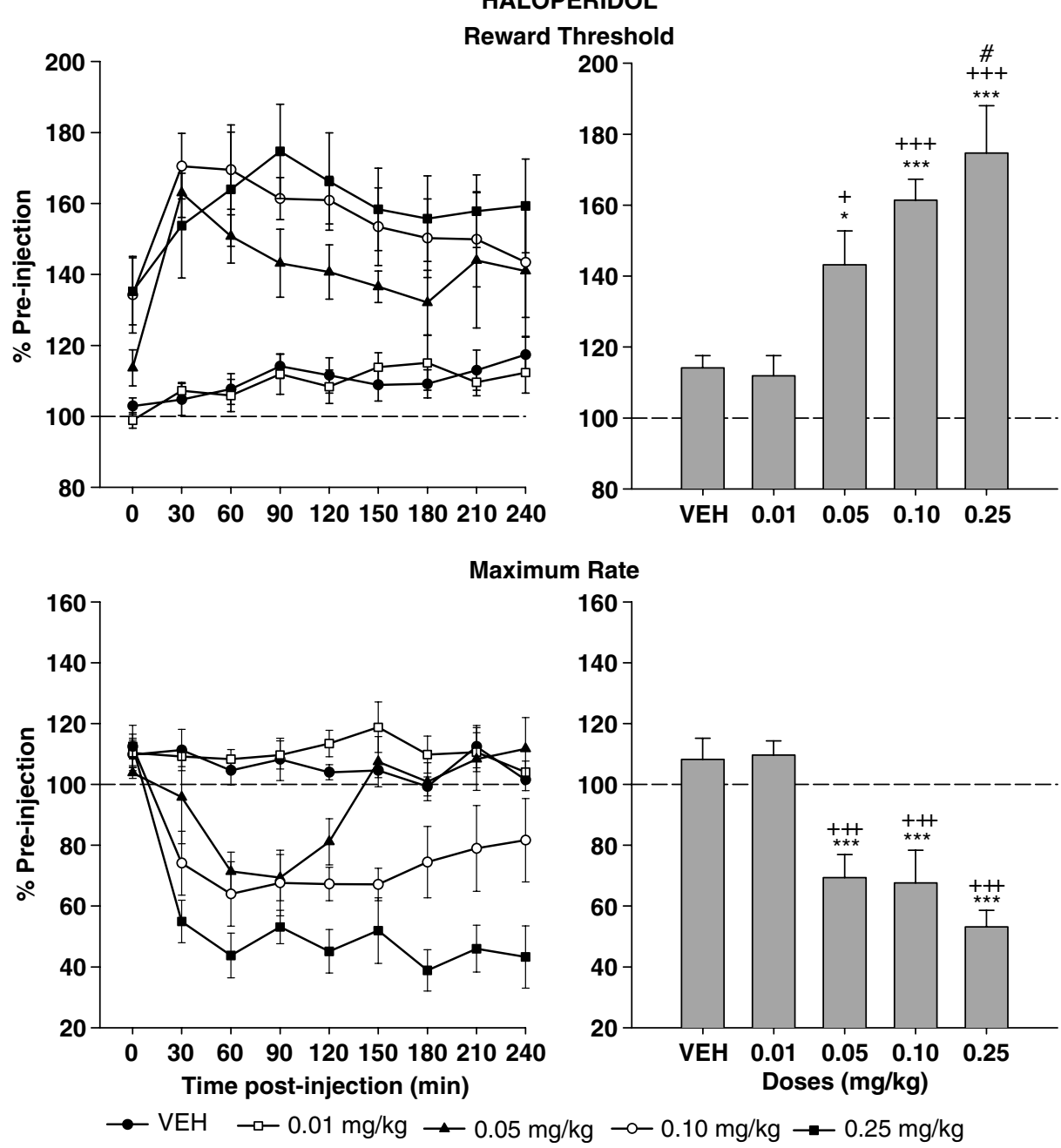

Figure 2 Group mean $( \pm$ SEM) of reward threshold and maximum rate induced by different doses of haloperidol expressed as percent of baseline. The top and bottom left-hand panels show the time course of reward threshold and maximum rates, respectively, for rats that responded during one or more time periods ( $n$ is different for several time periods owing to cessation of responding). The top right panel shows that haloperidol induced a dose-dependent

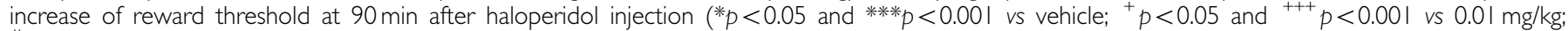
${ }^{\#} p<0.05 \mathrm{vs} 0.05 \mathrm{mg} / \mathrm{kg}$ ). The bottom right panel shows that haloperidol induced a dose-dependent decrease of maximum rate (**** $p<0.00 \mathrm{I} v \mathrm{v}$ vehicle and ${ }^{++} p<0.00 \mathrm{I}$ vs $\left.0.01 \mathrm{mg} / \mathrm{kg}\right)$. VEH and $0.01 \mathrm{mg} / \mathrm{kg}(n=9), 0.05 \mathrm{mg} / \mathrm{kg}(n=7), 0.10 \mathrm{mg} / \mathrm{kg}(n=7)$, and $0.25 \mathrm{mg} / \mathrm{kg}(n=6)$.

(0.05 and $0.1 \mathrm{mg} / \mathrm{kg}$ ) and $90 \mathrm{~min}(0.25 \mathrm{mg} / \mathrm{kg}$; top left panel); the mean maximal suppression reached near $75 \%$ and was observed at the highest dose. A one-way ANOVA was performed on data collected at the time of peak time plasma concentration (see Kapur et al, 2003) for those rats that did not stop responding at this time period, revealing a significant effect of treatment $\left(\mathrm{F}_{(4,31)}=13,1, p<0.0001\right)$. Post hoc analysis showed that $0.05 \mathrm{mg} / \mathrm{kg}$ was the lowest effective dose, and that the increase in threshold produced by $0.25 \mathrm{mg} / \mathrm{kg}$ was statistically different than that measured at $0.05 \mathrm{mg} / \mathrm{kg}$ (top right panel). In those animals that did not stop responding, haloperidol produced a dose-dependent suppression of maximum rate (Figure 2, bottom panel); the one-way ANOVA performed on data collected at 90 min yielded a significant effect $\left(\mathrm{F}_{(4,31)}=14,2, p=0.0001\right)$. As seen with the M50 measure, the threshold dose was $0.05 \mathrm{mg} / \mathrm{kg}$ and the suppression measured at the highest dose tended to be stronger than that measured at 0.05 and
$0.1 \mathrm{mg} / \mathrm{kg}$. It is noteworthy that at the threshold dose, recovery from suppression of maximum rate occurs at a time period where reward is still suppressed.

Contrary to clozapine and haloperidol, the selective 5-HT2a receptor antagonist M100907 had no effect on reward threshold at any of the doses tested during the 4-h test period (Figure 3, top panel; $\mathrm{F}_{(3,28)}=0.10 ; p=0.99$ ) and did not change the maximum rate (Figure 3, bottom panel; $\left.\mathrm{F}_{(3,28)}=1.42 ; p=0.26\right)$.

\section{Experiment 2: Core Body Temperature}

In order to insure that M100907 was physiologically active at the doses we used, we tested its effectiveness at blocking the increase in core body temperature induced by the nonselective 5-HT2 agonist DOI, a well-known 5-HT2mediated effect (Mazzola-Pomietto et al, 1995; Salmi and Ahlenius, 1998). Treatment with DOI alone produced a 
M100907
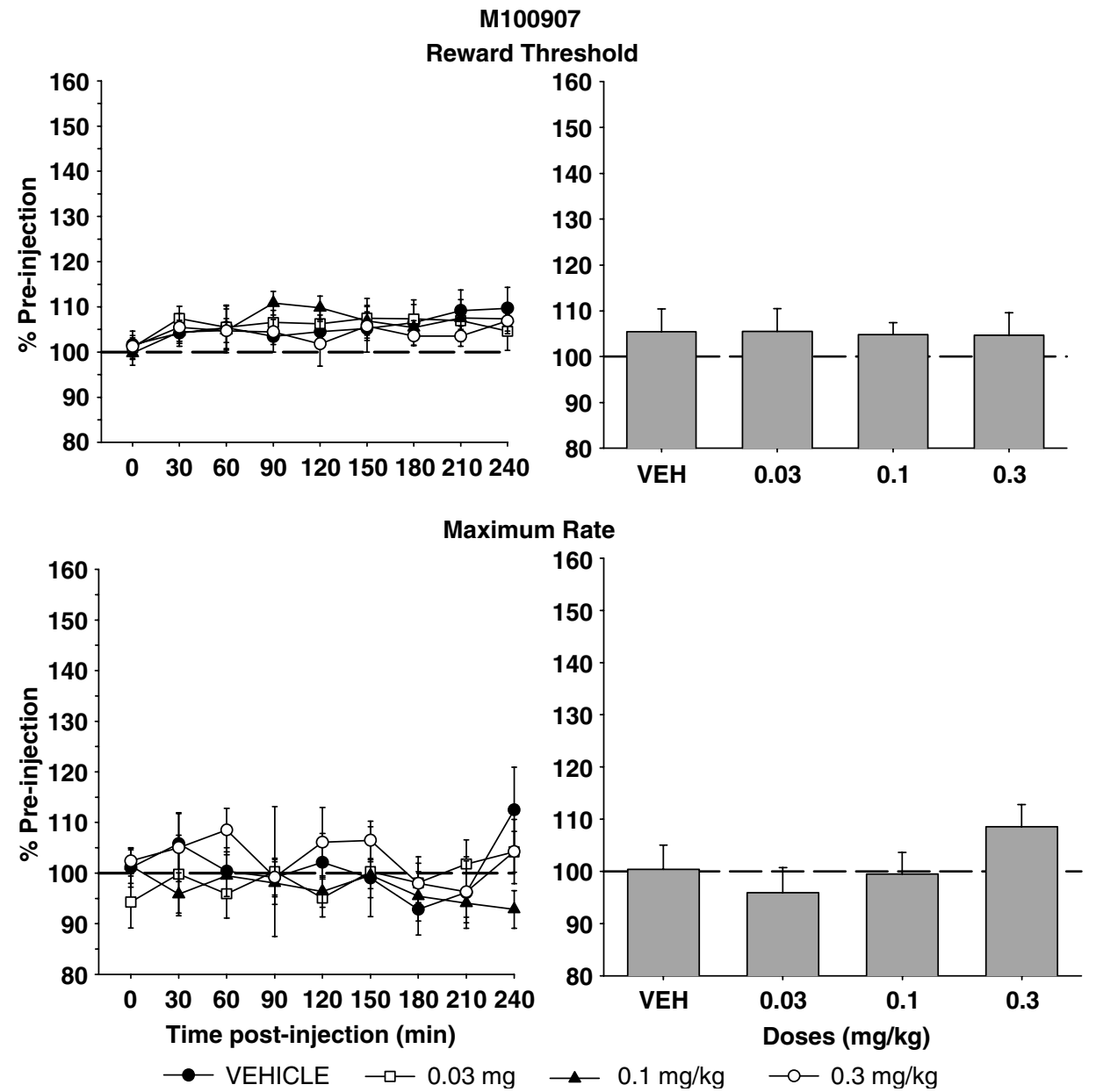

Figure 3 Group mean $( \pm$ SEM) of reward threshold and maximum rate induced by different doses of MI 00907 expressed as percent of baseline ( $n=8)$. The top and bottom left-hand panels show the time course of reward threshold and maximum rate, respectively. The top and bottom right-hand panels show reward threshold and maximum rate, respectively, at 60 min after MI 00907 injection. MI 00907 had no effects on reward threshold or maximum rate.

significant increase in temperature that was prevented by M100907 at a dose of $0.3 \mathrm{mg} / \mathrm{kg}$ (Figure 4). The analysis of variance yielded a significant effect of treatment $\left(\mathrm{F}_{3,28}=5.0\right.$; $p<0.01)$ and post hoc tests confirmed that DOI increased temperature above control (VEH + VEH) and that M100907 prevented this increase. There was no difference in baseline temperature between the groups.

\section{Experiment 3: Haloperidol + M100907 in BSR}

To verify whether 5-HT2a blockade alters the effect of D2 blockade on BSR, and produces effects that resemble those of clozapine, we tested the effects of a combined treatment with haloperidol and M100907 $(0.3 \mathrm{mg} / \mathrm{kg})$. Two doses of haloperidol were tested based on data collected in experiment 1 , a subthreshold dose $(0.01 \mathrm{mg} / \mathrm{kg})$ and a suprathreshold dose $(0.05 \mathrm{mg} / \mathrm{kg})$. As expected, haloperidol, at the lower dose $(0.01 \mathrm{mg} / \mathrm{kg})$, and M100907 alone, did not alter reward threshold, nor did it change it when coadministered (Figure 5, top left panel). The two-way ANOVA revealed no effect of treatment $\left(\mathrm{F}_{(3,28)}=0.88 ; p=0.46\right)$ and no effect of time $\left(\mathrm{F}_{(8,224)}=0.90 ; p=0.52\right)$. Besides, there was no effect of treatment at $60 \mathrm{~min}$ (top right panel) after the injections $\left(\mathrm{F}_{(3,28)}=0.326 ; p=0.81\right)$. Likewise, the two-way ANOVA

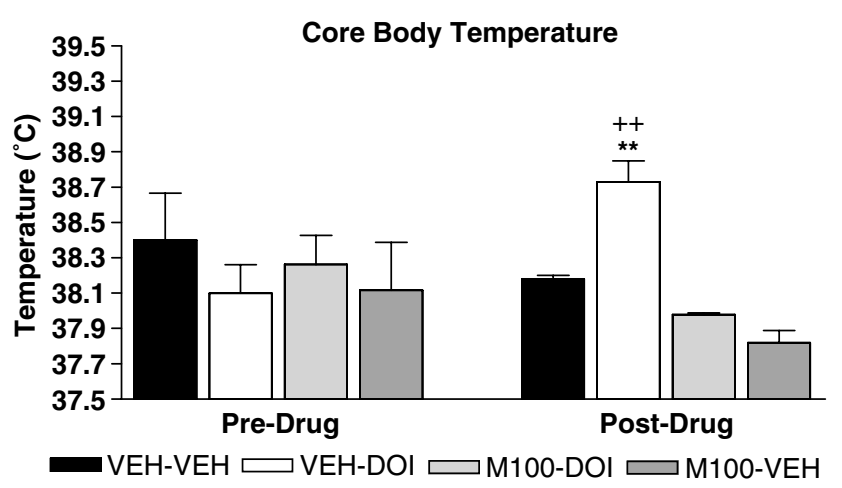

Figure 4 Rectal temperature after injection of DOI ( I mg/kg), MI00907 $(0.3 \mathrm{mg} / \mathrm{kg})$, or the combination of the two. DOl induced a significant increase in core body temperature vs vehicle $(* * p<0.01)$ and vs $\mathrm{MI} 00907+\mathrm{DOI}\left({ }^{++} p<0.0 \mathrm{I}\right) \cdot \mathrm{N}=8$.

revealed no effect of treatment $\left(\mathrm{F}_{(3,28)}=1.92 ; p=0.15\right)$ on maximum rate measured at $60 \mathrm{~min}$ (bottom right panel). The ANOVA performed on the time course data (bottom left panel) revealed a significant effect of time $\left(\mathrm{F}_{(8,224)}=2.24 ; p=0.03\right)$, but no effect of treatment 
HALOPERIDOL $(0.01 \mathrm{mg} / \mathrm{kg})+$ M100907 $(0.3 \mathrm{mg} / \mathrm{kg})$
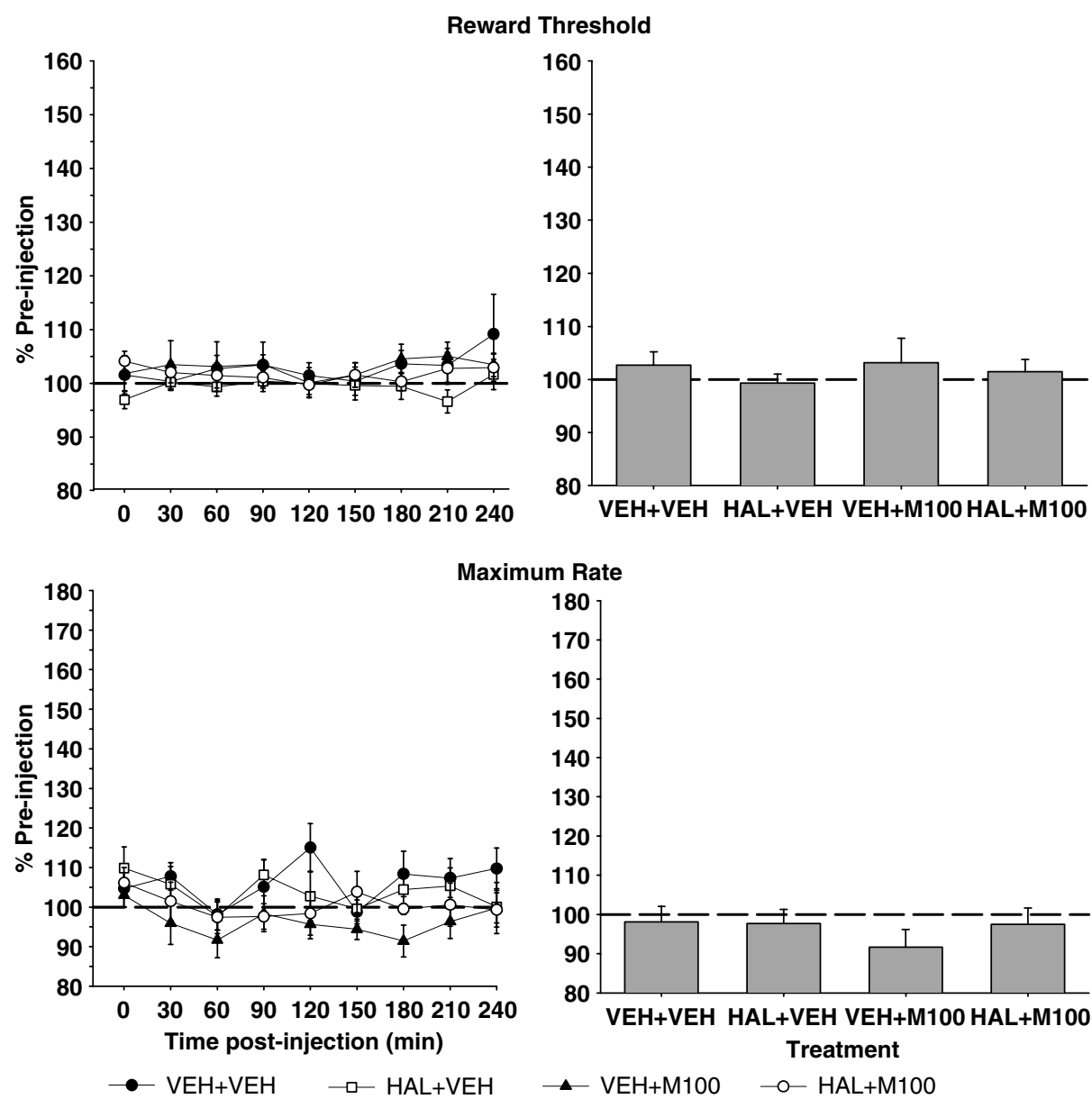

Figure 5 Group mean $( \pm S E M)$ of reward threshold and maximum rate induced by haloperidol $(0.01 \mathrm{mg} / \mathrm{kg}), \mathrm{Ml} 00907(0.3 \mathrm{mg} / \mathrm{kg})$, or their coadministration, expressed as percent of baseline. The top and bottom left-hand panels show the time course of reward threshold and maximum rate, respectively. The top and bottom right-hand panels show reward threshold and maximum rate respectively, 60 min following drug injection. The subthreshold dose of haloperidol alone or in combination with Ml00907 did not significantly change reward threshold and maximum rate. $\mathrm{N}=8$.

$\left(\mathrm{F}_{(3,28)}=0.572 ; p=0.64\right)$ nor of treatment by time interaction $\left(\mathrm{F}_{(24,224)}=0.96 ; p=0.53\right)$.

With the $0.05 \mathrm{mg} / \mathrm{kg}$ dose of haloperidol (Figure 6, top left panel), the two-way ANOVA revealed a significant effect of treatment on reward threshold $\left(\mathrm{F}_{(3,50)}=25.47 ; p<0.0001\right)$, a significant effect of time $\left(\mathrm{F}_{(8,400)}=8.89 ; p<0.0001\right)$, and a significant interaction of treatment by time $\left(\mathrm{F}_{(24,400)}=4.37\right.$; $p<0.0001)$. In addition, there was a significant effect of treatment at $60 \mathrm{~min}$ (top right panel) postinjections $\left(\mathrm{F}_{(3,50)}=31.06 ; p<0.0001\right)$. Duncan's post hoc tests showed that haloperidol alone increased threshold significantly compared to the vehicle at all times postinjection. M100907 induced a significant attenuation of haloperidol-induced increase in threshold at $0,60,90$, and $120 \mathrm{~min}$ after the injection of the drugs. Even though the coadministration of haloperidol and M100907 attenuated the effect of haloperidol alone on threshold $(p<0.05)$, threshold was still significantly higher than that obtained under vehicle treatment at all times, except at $210 \mathrm{~min}$, postinjection.

Neither haloperidol $(0.05 \mathrm{mg} / \mathrm{kg})$ alone nor when coadministered with M100907 produced a variation of maximum rate at the doses used in this experiment (Figure 6, bottom left panel). The two-way ANOVA revealed no effect of treatment $\left(\mathrm{F}_{(3,50)}=0.47 ; p=0.70\right)$ or time $\left(\mathrm{F}_{(8,400)}=1.0\right.$; $p=0.44$ ), and was so at $60 \mathrm{~min}$ (bottom right panel) after the injections $\left(\mathrm{F}_{(3,50)}=0.20 ; p=0.89\right)$.

\section{DISCUSSION}

This study was aimed at better understanding the contribution of 5-HT2a blockade to the attenuation of BSR by two antipsychotic drugs, clozapine and haloperidol. A first experiment replicated previous results (Greenshaw, 1993; Boye and Rompré, 2000) and showed that clozapine produced a dose-dependent attenuation of reward as inferred from the increase in frequency threshold. Clozapine was effective at $7.5 \mathrm{mg} / \mathrm{kg}$, but not $1.0 \mathrm{mg} / \mathrm{kg}$, and increasing the dose up to $30 \mathrm{mg} / \mathrm{kg}$ did not produce significantly higher reward attenuation, at least in those animals that still responded to the stimulation. Such a saturation of the reward attenuation effect is consistent with previous results obtained with mesencephalic reward sites (Boye and Rompré, 2000). It is unlikely that this effect can 
HALOPERIDOL (0.05 mg/kg) + M100907 (0.3 mg/kg)

Reward Threshold
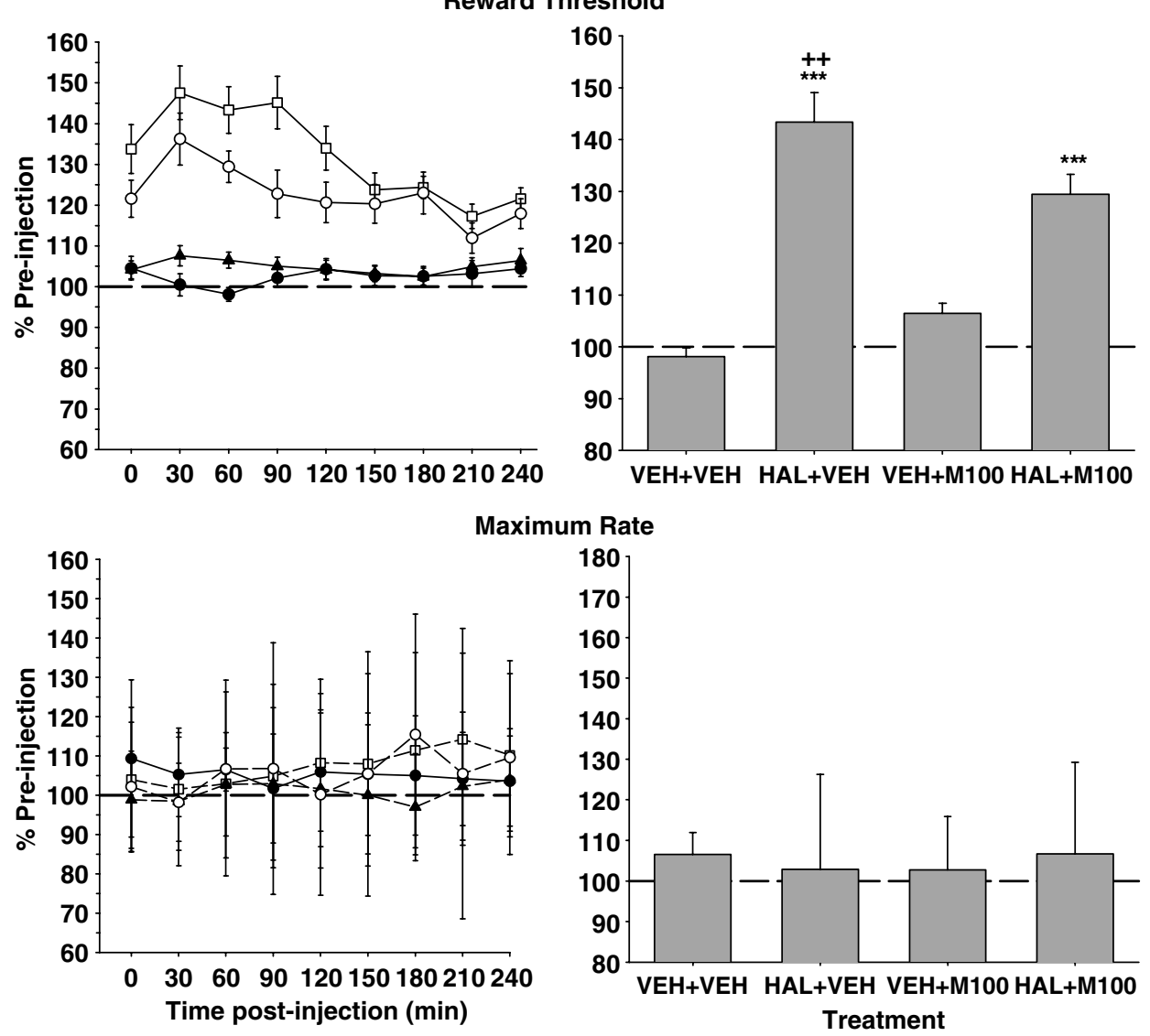

- VEH+VEH $\rightarrow$ - HAL+VEH

VEH+M100

- - HAL+M100

Figure 6 Group mean ( \pm SEM) of reward threshold and maximum rate induced by haloperidol $(0.05 \mathrm{mg} / \mathrm{kg}), \mathrm{Ml} 00907(0.3 \mathrm{mg} / \mathrm{kg}), 0 \mathrm{r}$ their coadministration expressed as percent of baseline. The top and bottom left-hand panels show the time course of reward threshold and maximum rate, respectively. The top right-hand panel shows that a suprathreshold dose of haloperidol alone or in combination with MI 00907 induced a significant increase of reward threshold, $60 \mathrm{~min}$ after injection (**** $p<0.00 \mathrm{I}$ vs vehicle). However, the increase in reward threshold induced by haloperidol alone was higher than the one induced by the coadministration of the two drugs $\left({ }^{++} p<0.0 \mathrm{I}\right)$. The bottom right-hand panel shows that haloperidol did not induce a change in maximum rate. $\mathrm{VEH}(n=12), \mathrm{HAL}+\mathrm{VEH}(n=13), \mathrm{VEH}+\mathrm{M}(n=15)$, and $\mathrm{HAL}+\mathrm{M}(n=14)$.

be attributed to the development of tolerance due to the use a within-subject design as measures reward attenuation obtained after two tests with the lowest effective dose $(7.5 \mathrm{mg} / \mathrm{kg})$, one during and one at the end of the experiment, were not different.

At each dose that it attenuated reward, clozapine produced complete cessation of responding in a significant number of animals at several time periods during the test. Two hypotheses may account for this behavioral suppression, either reward was completely blocked or motor impairment was so strong that the animals were unable to produce the operant response. The latter hypothesis predicts that clozapine will produce a progressive, dosedependent, suppression of maximum rate. Miliaressis et al (1986) showed that a decrease in maximum rate of responding indicates that a treatment interfered with the motor capacities of the animal to produce an operant response; they also showed that it has a minimal effect on the frequency threshold as measured with the present psychophysical method. Previous studies (Greenshaw, 1993; Boye and Rompré, 2000) reported a decrease in maximum rate following clozapine, an effect that was not observed in the present study. Differences in the type of operant responses and in the algorithm used to infer drug-induced changes in maximum rate are most likely to account for the present finding. A lack of effect on this measure of performance suggests that the failure of responding was more likely due to complete blockade of the rewarding effectiveness of the stimulation. Clozapine interacts with several neurotransmitter systems; however, it is its interaction with D2 receptors that is hypothesized to mainly account for its reward-attenuating effect. BSR is highly sensitive to changes in DA neurotransmission. Drugs that increase central DA impulse flow and central DA release enhance reward, whereas drugs that decrease DA impulse flow and DA release, or that block postsynpatic DA receptors, attenuate reward (see Wise and Rompre, 1989). In fact, Gallistel and Davis (1983) showed that the reward attenuation effect of a large number of drugs is correlated with their affinity for D2 receptors. Consistent with this, we replicated previous results (Greenshaw, 1993; Boye and Rompré, 2000) and found a dose-dependent suppression of 
reward and of maximum rate with haloperidol, a drug that displays a much higher affinity for D2 receptors than clozapine. The low affinity of clozapine for D2 receptors, which results in a moderate level of central D2 receptor occupancy (Kapur et al, 2003), could well explain its lower maximal reward attenuation than that produced by haloperidol, but it is unlikely to account for the complete blockade of reward. The number of animals that ceased to respond was in fact higher after clozapine than after haloperidol. One possible explanation is that clozapine interacts with another neurotransmitter system that somehow synergizes with its D2 effect to suppress reward.

As mentioned above, clozapine displays a high affinity for 5-HT2a receptors, and previous studies have shown that antagonism at this receptor produces a functional enhancement of D2 antagonism in certain models. Selective blockade of 5-HT2a, for instance, enhances the effect of D2 receptor blockade on ventral midbrain DA cell firing (Olijslagers et al, 2004, 2005) and on limbic DA release (Bonaccorso et al, 2002; Liégeois et al, 2002). Wadenberg et al $(1996,2001)$ also showed that blockade of 5-HT2a receptors amplifies the suppression effect of haloperidol, and of raclopride, on the CAR response.

In order to determine the relevance of a 5-HT2a/D2 interaction to the reward attenuation induced by antipsychotic drugs, we studied first the effect of M100907, a selective 5-HT2a antagonist. Over a range of doses that produce low to near-complete central 5-HT2a blockade, as measured with in vivo occupancy (S Kapur, unpublished observations), M100907 did not alter reward nor maximum rate. The fact that at the highest dose tested M100907 blocked the hyperthermic effect of DOI, a 5-HT2a/c agonist, confirms that the drug was pharmacologically active. The negative results suggest then that 5-HT2a receptors do not exert a tonic modulation on the reward-relevant pathway. This conclusion is consistent with previous results showing that systemic injections of similar doses of M100907 have no effect on spontaneous DA-dependent behavioral responses (Moser et al, 1996; Palfreyman et al, 1993; Sorensen et al, 1993), on basal limbic DA release (Bonaccorso et al, 2002; Liégeois et al, 2002), and on spontaneous firing rate of ventral midbrain DA neurons (Palfreyman et al, 1993; Sorensen et al, 1993). Previous studies have shown however that systemic injection of M100907 attenuates amphetamine- and cocaine-induced locomotor activity (Sorensen et al, 1993; Palfreyman et al, 1993; Moser et al, 1996; McMahon and Cunningham, 2001). M100907 also reduces cocaine-induced locomotion when injected locally into the ventral midbrain but not the nucleus accumbens, an effect consistent with localization of 5-HT2a within the ventral midbrain (Doherty and Pickel, 2000). These findings show that M100907 has an attenuating effect on DA-mediated behaviors. As diencephalic rewarding stimulation increases DA and 5-HT neurotransmission (Blaha and Phillips, 1990; Nakahara et al, 1989, 1992) and is very sensitive to changes in ventral midbrain neurotransmission, M100907 should have attenuated BSR. This suggests then that 5-HT2a receptors do not have such a modulatory role in the reward-relevant DA pathway activated by diencephalic electrical stimulation.

We also studied the effect of M100907 on a sub- and suprathreshold dose of haloperidol. As mentioned pre- viously, M100907 attenuates and potentiates respectively the release of DA initiated by haloperidol within the nucleus accumbens and the PFC (Liégeois et al, 2002). It also potentiates the suppression effect of haloperidol on CAR response (Wadenberg et al, 1996, 2001). Our results show that M100907 had no effect on reward and on maximum rate when it was administered with a subthreshold dose of haloperidol. But when it was administered in combination with a dose of haloperidol that produced a significant reward attenuation, it produced a reduction of this attenuation. This result supports the hypothesis that 5HT2a receptors modulate the reward-relevant pathway when its function is altered by DA antagonist; it is consistent with the lack of effect of M100907 on amphetamine-induced enhancement of reward (Moser et al, 1996). The direction of this modulation was somewhat unexpected. In effect M100907, injected systemically or directly into the nucleus accumbens, does not reduce but rather enhances the effect of haloperidol on CAR, a behavior that, just like responding for reward, is sensitive to DA neurotransmission and to antipsychotic drugs (see Wadenberg and Hicks, 1999). Consistently, M100907 was found to reduce haloperidol-induced DA release in the nucleus accumbens (Liégeois et al, 2002; but see Andersson et al, 1995), an effect that is likely to enhance the functional consequences of postsynaptic blockade, and that is predictive of a potentiation of the reward attenuation effect of haloperidol. In effect, there is a substantial body of evidence showing that release of DA in the nucleus accumbens plays a key role in reward. Blockade of DA receptors in this region reduces BSR (Stellar and Corbett, 1989; Nakajima and Patterson, 1997), whereas injection of amphetamine, a drug that increases local DA release, enhances reward (Colle and Wise, 1988; Ranaldi and Beninger, 1994). How can we explain the reduction effect of M100907 on the attenuation of haloperidol on reward?

Whereas M100907 attenuates haloperidol-induced DA release in the nucleus accumbens, it potentiates it in the PFC (Liégeois et al, 2002), an effect that would be consistent with the present results in as much as increased DA release in this region enhances reward. Some empirical findings tend to support this hypothesis. First, the PFC is an important component of the reward-relevant pathway (Tzschentke, 2000). Second, BSR is induced by electrical stimulation of the PFC (Mora and Ferrer, 1986) and is sensitive to DA neurotransmission (Corbett, 1990; Hand and Franklin, 1983). Third, rewarding stimulation applied to the MFB and to the PFC induces Fos expression in overlapping limbic regions (Arvanitogiannis et al, 2000) suggesting activation of a common neural substrate. Fourth, Nakahara et al (2000) have reported that rewarding stimulation applied to the MFB increases 5-HT and DA neurotransmission in the PFC, hence providing empirical support for a reward-relevant 5-HT-DA interaction in this region. Other studies, however, rather suggest that reward induced by electrical stimulation of the MFB and the PFC is mediated by functionally independent neural pathways (Robertson, 1989; Schenk and Shizgal, 1985; Singh et al, 1997; Duvauchelle et al, 1998).

Clinical studies have reported that dysphoria (including anhedonia) is relatively common in patients treated with antipsychotic medications (Voruganti and Awad, 2004), a side effect that likely results from disruption of 
the reward-relevant pathway. Occurrence of dysphoria is correlated with D2 receptor blockade (de Haan et al, 2000), just like the attenuation of BSR (Gallistel and Davis, 1983). The present results provide some evidence that combined blockade of D2 and 5-HT2a may reduce anhedonia induced by haloperidol, and also provide support for the hypothesis that the 5-HT2 receptors may contribute to reward-sparing properties of atypical antipsychotics, like clozapine (Awad, 2004).

\section{ACKNOWLEDGEMENTS}

This work was supported by the Canadian Institutes of Health Research. We are grateful to Sandra Boye and Pat Bauco for helpful discussion and thank Claude Bouchard for his technical help.

\section{REFERENCES}

Andersson JL, Nomikos GG, Marcus M, Hertel P, Mathe JM, Svensson TH (1995). Ritanserin potentiates the stimulatory effects of raclopride on neuronal activity and dopamine release selectivity in the mesolimbic dopaminergic system. Naunyn Schmiedebergs Arch Pharmacol 352: 374-385.

Arvanitogiannis A, Tzschentke TM, Riscaldino L, Wise RA, Shizgal P (2000). Fos expression following self-stimulation of the medial prefrontal cortex. Behav Brain Res 107: 123-132.

Awad AG (2004). Second generation antipsychotics: looking beyond efficacy. Can J Psychiat 49: 283-284.

Blaha CD, Phillips AG (1990). Application of in vivo electrochemistry to the measurement of changes in dopamine release during intracranial self-stimulation. J Neurosci Methods 34: 125133.

Bonaccorso S, Meltzer HY, Li Z, Dai J, Alboszta AR, Ichikawa J (2002). SR46349-B, a 5-HT(2A/2C) receptor antagonist, potentiates haloperidol-induced dopamine release in rat medial prefrontal cortex and nucleus accumbens. Neuropsychopharmacology 27: 430-441.

Boye SM, Rompré PP (1996). Effect of pimozide on self-stimulation threshold under a continuous and fixed-interval schedule of reinforcement. Behav Brain Res 78: 243-245.

Boye SM, Rompré PP (2000). Behavioral evidence of depolarization block of dopamine neurons after chronic treatment with haloperidol and clozapine. J Neurosci 20: 1229-1239.

Clark G (1981). Staining Procedures. Williams and Wilkins: Baltimore.

Colle LM, Wise RA (1988). Effects of nucleus accumbens amphetamine on lateral hypothalamic brain stimulation reward. Brain Res 459: 361-368.

Corbett D (1990). Ketamine blocks the plasticity associated with prefrontal cortex self-stimulation. Pharmacol Biochem Behav 37: 685-688.

de Haan L, Lavalaye J, van Bruggen M, van Nimwegen L, Booij J, van Amelsvoort $\mathrm{T}$ et al (2000). Subjective experience and dopamine D2 receptor occupancy in patients treated with antipsychotics: clinical implications. Can J Psychiat 49: 290-296.

Doherty MD, Pickel VM (2000). Ultrastructural localization of the serotonin $2 \mathrm{~A}$ receptor in dopaminergic neurons in the ventral tegmental area. Brain Res 864: 176-185.

Duvauchelle CL, Fleming SM, Kornetsky C (1998). Prefrontal cortex infusions of SCH 23390 cause immediate and delayed effects on ventral tegmental area stimulation reward. Brain Res 811: 57-62.

Gallistel CR, Davis AJ (1983). Affinity for the dopamine D2 receptor predicts neuroleptic potency in blocking the reinforcing effect of MFB stimulation. Pharmacol Biochem Behav 19: 867-872.

Greenshaw AJ (1993). Differential effects of ondansetron, haloperidol and clozapine on electrical self-stimulation of the ventral tegmental area. Behav Pharmacol 4: 479-485.

Farrell M, Boys A, Bebbington P, Brugha T, Ciod J, Jenkins R et al (2002). Psychosis and drug dependence: results from a national survey of prisoners. Br J Psychiat 181: 393-398.

Hand TH, Franklin KB (1983). The influence of amphetamine on preference for lateral hypothalamic versus prefrontal cortex or ventral tegmental area self-stimulation. Pharmacol Biochem Behav 18: 695-699.

Hicks PB, Browning J, Barwick S, Jones D, Wadenberg ML, Richter JT et al (1999). M100,907 acts at both the nucleus accumbens and the prefrontal cortex to mediate the enhancement of suppression of conditioned avoidance response by haloperidol. Abstracts of the VIIth International Congress on Schizophrenia Research Santa Fe, New Mexico, USA, 17-21 April 1999. Schizophr Res 36: 111-122.

Hietala J, Syvalahti E, Vuorio K, Rakkolainen V, Bergman J, Haaparanta $M$ et al (1995). Presynaptic dopamine function in striatum of neuroleptic-naive schizophrenic patients. Lancet 346: 1130-1131.

Kane J, Honigfeld G, Singer J, Meltzer H (1988). Clozapine for the treatment-resistant schizophrenic. A double-blind comparison with chlorpromazine. Arch Gen Psychiat 45: 789-796.

Kapur S, Mamo D (2003). Half a century of antipsychotics and still a central role for dopamine D2 receptors. Prog Neuropsychopharmacol Biol Psychiatry 27: 1081-1090.

Kapur S, VanderSpek SC, Brownlee BA, Nobrega JN (2003). Antipsychotic dosing in preclinical models is often unrepresentative of the clinical condition: a suggested solution based on in vivo occupancy. J Pharmacol Exp Ther 305: 625-631.

Krystal JH, Perry Jr EB, Gueorguieva R, Belger A, Madonick SH, biDargham A et al (2005). Comparative and interactive human psychopharmacologic effects of ketamine and amphetamine: implications for glutamatergic and dopaminergic model psychoses and cognitive function. Arch Gen Psychiat 62: 985-994.

Kuroki T, Meltzer HY, Ichikawa J (2003). 5-HT 2A receptor stimulation by DOI, a $5-\mathrm{HT} 2 \mathrm{~A} / 2 \mathrm{C}$ receptor agonist, potentiates amphetamine-induced dopamine release in rat medial prefrontal cortex and nucleus accumbens. Brain Res 272: 216-221.

Laruelle M (2000). The role of endogenous sensitization in the pathophysiology of schizophrenia: implications from recent brain imaging studies. Brain Res Rev 31: 371-384.

Leucht S, Barnes TRE, Kissling W, Engel RR, Correll C, Kane JM (2003). Relapse prevention in schizophrenia with new-generation antipsychotics: a systematic review and exploratory metaanalysis of randomized, controlled trials. Am J Psychiat 160: 1209-1222.

Leucht S, Pitschel-Walz G, Abraham D, Kissling W (1999). Efficacy and extrapyramidal side-effects of the new antipsychotics olanzapine, quetiapine, risperidone, and sertindole compared to conventional antipsychotics and placebo. A meta-analysis of randomized controlled trials. Schizophr Res 35: 51-68.

Liégeois JF, Ichikawa J, Meltzer HY (2002). 5-HT(2A) receptor antagonism potentiates haloperidol-induced dopamine release in rat medial prefrontal cortex and inhibits that in the nucleus accumbens in a dose-dependent manner. Brain Res 947: 157-165.

Mazzola-Pomietto P, Aulakh CS, Wozniak KM, Hill JL, Murphy DL (1995). Evidence that 1-(2,5-dimethoxy-4-iodophenyl)-2-aminopropane (DOI)-induced hyperthermia in rats is mediated by stimulation of 5-HT2a receptors. Psychopharmacology (Berlin) 117: 193-199.

McMahon LR, Cunningham KA (2001). Antagonism of 5-hydroxytryptamine(2a) receptors attenuates the behavioral effects of cocaine in rats. J Pharmacol Exp Ther 297: 357-363. 
Meltzer HY (1999). The role of serotonin in antipsychotic drug action. Neuropsychopharmacology 21: 106S-115S.

Miliaressis E, Rompre PP, Laviolette P, Philippe L, Coulombe D (1986). The curve-shift paradigm in self-stimulation. Physiol Behav 37: 85-91.

Mora F, Ferrer JM (1986). Neurotransmitters, pathways and circuits as the neural substrates of self-stimulation of the prefrontal cortex: facts and speculations. Behav Brain Res 22: 127-140.

Moser PC, Moran PM, Frank RA, Kehne JH (1996). Reversal of amphetamine-induced behaviours by MDL 100,907, a selective 5-HT2A antagonist. Behav Brain Res 73: 163-167.

Nakahara D, Fuchikami K, Ozaki N, Iwasaki T, Nagatsu T (1992). Differential effect of self-stimulation on dopamine release and metabolism in the rat medial frontal cortex, nucleus accumbens and striatum studied by in vivo microdialysis. Brain Res 574: 164-170.

Nakahara D, Nakamura M, Furkawa H, Furuno N (2000). Intracranial self-stimulation increases differentially in vivo hydroxylation of tyrosine but similarly in vivo hydroxylation of tryptophan in rat medial prefrontal cortex, nucleus accumbens and striatum. Brain Res 864: 124-129.

Nakahara D, Ozaki N, Miura Y, Miura H, Nagatsu T (1989). Increased dopamine and serotonin metabolism in rat nucleus accumbens produced by intracranial self-stimulation of medial forebrain bundle as measured by in vivo microdialysis. Brain Res 495: $178-181$.

Nakajima S, Patterson RL (1997). The involvement of dopamine D2 receptors, but not D3 or D4 receptors, in the rewarding effect of brain stimulation in the rat. Brain Res 760: 74-79.

Olijslagers JE, Perlstein B, Werkman TR, McCreary AC, Siarey R, Kruse CG et al (2005). The role of 5-HT(2A) receptor antagonism in amphetamine-induced inhibition of A10 dopamine neurons in vitro. Eur J Pharmacol 520: 77-85.

Olijslagers JE, Werkman TR, McCreary AC, Siarey R, Kruse CG, Wadman WJ (2004). 5-HT2 receptors differentially modulate dopamine-mediated auto-inhibition in A9 and A10 midbrain areas of the rat. Neuropharmacology 46: 504-510.

Palfreyman MG, Schmidt CJ, Sorensen SM, Dudley MW, Kehne JH, Moser $\mathrm{P}$ et al (1993). Electrophysiological, biochemical and behavioral evidence for 5-HT2 and 5-HT3 mediated control of dopaminergic function. Psychopharmacology (Berlin) 112: S60-S67.

Paxinos G, Watson C (1986). The Rat Brain in Stereotaxic Coordinates. Academic Press: New York.

Ranaldi R, Beninger RJ (1994). Rostral-caudal differences in effects of nucleus accumbens amphetamine on VTA ICSS. Brain Res 642: $251-258$

Reith J, Benkelfat C, Sherwin A, Yasuhara Y, Kuwabara H, Andermann F et al (1994). Elevated dopa decarboxylase activity in living brain of patients with psychosis. Proc Natl Acad Sci USA 91: 11651-11654.
Robertson A (1989). Multiple reward systems and the prefrontal cortex. Neurosci Biobehav Rev 13: 163-170.

Rompré PP (1995). Psychostimulant-like effect of central microinjection of neurotensin on brain stimulation reward. Peptides 16: 1417-1420.

Salmi P, Ahlenius S (1998). Evidence for functional interactions between 5-HT1a and 5-HT2a receptors in rat thermoragulatory mechanisms. Pharmacol Toxicol 82: 122-127.

Schenk S, Shizgal P (1985). The substrates for self-stimulation of the lateral hypothalamus and medial prefrontal cortex: a comparison of strength-duration characteristics. Physiol Behav 34: $943-949$.

Seeman P (1987). Dopamine receptors and the dopamine hypothesis of schizophrenia. Synapse 1: 133-152.

Singh J, Desiraju T, Raju TR (1997). Dopamine receptor sub-types involvement in nucleus accumbens and ventral tegmentum but not in medial prefrontal cortex: on self-stimulation of lateral hypothalamus and ventral mesencephalon. Behav Brain Res 86: 171-179.

Sorensen SM, Kehne JH, Fadayel GM, Humphreys TM, Ketteler HJ, Sullivan CK et al (1993). Characterization of the $5-\mathrm{HT}_{2}$ receptor antagonist MDL 100907 as a putative atypical antipsychotic: behavioral, electrophysiological and neurochemical studies. $J$ Pharmacol Exp Ther 266: 684-691.

Stellar JR, Corbett D (1989). Regional neuroleptic microinjections indicate a role for nucleus accumbens in lateral hypothalamic self-stimulation reward. Brain Res 477: 126-143.

Tzschentke TM (2000). The medial prefrontal cortex as a part of the brain stimulation reward system. Amino Acids 19: 211-219.

Voruganti L, Awad AG (2004). Neuroleptic dysphoria: towards a new synthesis. Psychopharmacology (Berlin) 171: 121-132.

Wadenberg ML, Browning JL, Young KA, Hicks PB (2001). Antagonism at $5-\mathrm{HT}_{2 \mathrm{~A}}$ receptors potentiates the effect of haloperidol in a conditioned avoidance response task in rats. Pharmacol Biochem Behav 68: 363-370.

Wadenberg ML, Hicks PB (1999). The conditioned avoidance response test re-evaluated: is it a sensitive test for the detection of potentially atypical antipsychotics? Neurosci Biobehav Rev 23: $851-862$.

Wadenberg ML, Hicks PB, Richter JT, Young KA (1998). Enhancement of antipsychoticlike properties of raclopride in rats using the selective serotonin ${ }_{2 \mathrm{~A}}$ receptor antagonist MDL 100,907. Biol Psychiat 44: 508-515.

Wadenberg ML, Salmi P, Jimenez P, Svensson T, Ahlenius S (1996). Enhancement of antipsychotic-like properties of the dopamine D2 receptor antagonist, raclopride, by the additional treatment with the 5-HT2 receptor blocking agent, ritanserin, in the rat. Eur Neuropsychopharmacology 6: 305-310.

Wise RA, Rompre PP (1989). Brain dopamine and reward. Annu Rev Psychol 40: 191-225. 